\title{
Behavioral therapy in diabetes mellitus and obesity
}

\section{I.Sal ${ }^{*}$}

Ildiko Kohlne Papp psychologist. PhD, Semmelweis University, Institute of Behavioral Sciences, Budapest

In Weimar, on the wall of Albert Schweitzer Museum, there is a memorial tablet which says: "The purpose of our life is to serve, to show solidarity and helpfulness." The humanist medical doctor, theologian, philosopher, organist could not have expressed more clearly our confession. Behavioral therapy integrates the cure of body and soul, which occasionally show some duality and opposition.

"The Behavioral therapy is an interdisciplinary field of science, which integrate behavioral and biomedical knowledge of health and disease, and use that knowledge for prevention, diagnosing, therapy, and rehabilitation." [1].

The claim to the integrative theorizing by means of medicine, epidemiology, psychology, physiology, sociology, anthropology, biology, and political science produced the interdisciplinary workshops of behavioural therapy in the United States, in the 1950s. The researchers realized, that while we got knew more and more about the human cells, organs, psychological functions, so we became immersed in the parts, we forgot the whole. We moved away from the understanding of the human phenomenon in its entirety, its relationship with nature [2]

There is a basic question of the behavioral sciences and behavioral therapy: what mechanism can explain, that social, and psychological factors, environmental impacts have an effect on some important disease's development and course, furthermore how these mechanisms can be used in prevention, therapy, and rehabilitation.

\section{Diabetes mellitus}

Diabetes is a model disease of behavior therapy [3]. It is estimated, that in $20002.8 \%$ of the world's population suffered from diabetes, according to forecasts it will be doubled to 2030 [4]. These statistical estimations likely underrate the real incidence, because nearly $50 \%$ of diabetics do not know about their illness [5]. The fact of diabetes mellitus doubles the age adjusted mortality [6].

According to our knowledge the evidence-based treatment of type 2 diabetes can lead to good prognosis and improve the life quality. In practice, the most of the patients do not keep the rules of selfmanagement: physical activity, healthy dining, and medication [7]. Every third diabetic does not comply with medical instructions for medication, the half of the patients eats unhealthy, furthermore twothirds of them have insufficient physical activity [8].

During the therapy of diabetes patients have to develop daily routines: measure blood sugar level, maybe give insulin several times per day, be on a diet, go in for sports, take some pills, so change lifestyle. The largest part of the treatment is in the hands of the patients. They have to make decisions every day, and these decisions have an effect on their physical condition, prognosis, the risk of developing complications. Because of these, the aim is to develop responsibility for themselves.
In the recent decades it is recognized, that the states of mind of patients have considerable effect on treatment of chronic diseases. According to WHO increasing the efficiency of interventions on healthy behaviour have much bigger effect on population health, than any development in health care.

\section{The physic effects of diabetes mellitus}

The diagnosis of diabetes has significant effect on the patient, and this reaction is influenced by some other factor too, for example the personality, knowledges about the disease, other diabetics in family, myths about the illness, contradictory information [9].

The way, on which specialists communication the diagnosis of diabetes, also influence how serious the patients find the illness, and how important they find the therapy. Many diabetics neglect the disease because of the mild symptoms and less invasive treatment (diet, drugs) of type 2 diabetes [10].

On the other hand, if patients find the diabetes too serious, it will also hinder the therapy, because of the active protection mechanism, like denial, trivializing [10]. Fear of complications, hyperglycaemia, hypoglycaemia also has negative effects on the patient's psychosocial status and cooperation in type 1 diabetes [11].

According to Howorka (1996), the acceptance of diabetes takes place in three stages, like mourning, based on Eric Berne's personality theory, and transactional analysis [12]:

1. Denial of reality. According to the personality theory of Berne, this functions like Child state.

\section{Depression. This is the function of the Parent state.}

3. Acquiescence, adjustment to the new reality. This is the Adult state.

Instead of Restitutio ad integrum, restitutio ad optimum will be the result of the process. The states have to be considered like dynamic processes. The dominance of denial can be reinforced and conserved by external influences. The communication problems of doctor-patient relationship can slow down, and maybe stop the mourning. In practice, the Parent state is addressed, the system of commands and prohibitions is built up. Doctor speaks about the importance and benefits of therapy; patient speaks about his fear and expectations of therapy (crossed transaction).

${ }^{\star}$ Correspondence to: Istvan Sal, Pensioner, Ildiko Kohlne Papp psychologist $\mathrm{PhD}$, Semmelweis University, Institute of Behavioral Sciences, Budapest, E-mail: dr.salistvan@vnet.hu

Received: August 05, 2019; Accepted: August 26, 2019; Published: September 09,2019 
Transactional analysis can be used for analyse the communication and the patient's behaviour. "Desire analysis": which part of my personality desire it? The receiving of the desired things is ensured by the proper relationship between "Child state", "Parent state", and "Adult state". For the successful therapy of a chronic disease all states of personality have to be addressed. According to the concept of transactional analysis, the intrinsic motivation fit for the Child state's desires, which is advocated by the Adult state's rationality. The significantly weaker extrinsic motivation is appointed by the commands and denials of Parent state. Motivation can be strengthened by positive feedbacks. This simplified explanation of motivation is consistent with the recent research results, and can be applied in behaviour-therapy practice $[13,14]$

A letter from a bulimic teacher: "With diabetes, you get into an enormous system of requirements. Independently your decisions. Sometimes the scale of requirements is bigger, than what you can accept. Spiritually, often doctors do not help you to accept the disease. After years you still cannot live together with the illness. The blood sugar diary will be happy. You measure for your own, but don't write it into the diary. Or you don't measure. The puncture is painful. The result of the measure is more painful. The deprecating blinks and words of doctors annihilate me resistance helplessness. But there are some specialists, who help the patient with unconditional acceptance. And after the aid of this doctor the diary will contain all of the measured values. And everything will be better. Thank you!"

Among chronic diseases, diabetes mellitus is one of the most physical, psychological and emotional challenging disease. Some diabetics produce burnout symptoms. Polonksy (1999) write down in his book some general attributions of diabetics, who feel, that they have tired of daily management of diabetes, they are overloaded and frustrated. In this situation the motivation of patients abates, they check their blood sugar level less times, neglect the diet and the drug treatment. They are frustrated and angry, they feel that the disease controls their life [15].

Consequently diabetes has serious psychological effects, included the feel of loss, anger, and the change of identity. The complex daily therapy is an enormous challenge. Diabetics are often sad, angry, overloaded, they feel remorse and shame [16]. This disease makes patients to feel doubtfulness, and fear of complications [17,18]. These negative feelings can hinder the active attendance in therapy, what debases patient's state of health.

Accordingly, diabetes influences every part of life. Apart from its serious medical and economic impact, it has notable psychological and quality of life influential effects. According to international researches, the quality of life of adult diabetics is significantly worse compared to the average population [11]. In accordance with the Hungarostudy research, which was made in 2005/2006 in Hungary, $9 \%$ of the full sample (4524 people) was diabetics (type 1 and type 2 was not differentiated), and they had worse quality of life, and state of health. Just some major details: $44.6 \%$ of diabetics judged their state of health bad or very bad, $96.9 \%$ of them felt that their medical status has deteriorated in the last 3 years. Quality of life indicators, which are connected to health (Burden of Disease Index, WHO Well-being Questionnaire, Beck Depression Inventory) show, that quality of life indicators of diabetics are significantly worse, than non-diabetics. More than $60 \%$ of responders report medium or serious decrease of performance, which refers to the unsatisfying rehabilitation. $44.8 \%$ of diabetics, who are under psychiatric treatment, are treated because of depression. It is even more astonishing, that $70 \%$ of diabetics, who are not under psychiatric treatment, feel, that they need psychological support [19].

In short, the quality of life of diabetics is worse than the others. The international data show, that the decadence of quality of life determinate the therapeutic cooperation [20]. Because of this, quality of life improvement methods have important role in diabetes care.

In the recent remedy it is concentrated on some (of course, very important) biomarkers, and the psychosocial factors are neglected. If the self-care does not working well, it will lead to discomfort, frustration, burnout, which debase the further treatment [21-23].

The new knowledges from quality of life researches have to improve the therapy of diabetes. There is a significant connection between the quality of life and the clinical effectiveness of diabetes therapy.

It is a shift from the traditional epidemiological approach, to a more comprehensive aspect, which takes into account the quality of life [24]. One of the main achievements of the health care's improvement in the last two deceased is that we have to observe the health care's quality from the patient's point of view [25]. The parameters, which indicate the patient's medical condition (blood pressure, blood glycose, lipids, HbA1c), are not always show the patient's psychological, functional, and social status.

\section{Psychopathology and diabetes mellitus}

According to researches, among diabetics it is two times more likely to have psychological illness, compared to non-diabetics [26,27]. The most common illnesses are the depression, anxiety disorders (generalized phobic, panic), and eating disorders [28-30].

The recognition of psychological symptoms is difficult, because the signs of hypoglycaemia and hyperglycaemia are familiar like the signs of depression and anxiety (fractiousness, concentration difficulties, tiredness, vertigo).

Changes in the patient's mood, sleeping habits, social activity, can be premonitory signs. In this situation it is recommended to refer the patient to psychiatrist, after the monitoring of the metabolic state.

\section{Depression}

According to Anderson's meta-analysis of 42 researches, the diabetes is two times likely among diabetics, than non-diabetics. The prevalence is twice higher among women, than men (28\% vs. $18 \%)$ [31]. Two more recent researches confirm these results $[32,33]$. According to estimations $20 \%$ of diabetic men, and $40 \%$ of diabetic women have at least one depressed episode during their life [34]. Most of the type 2 diabetics do not look for support correlate to depression [35]. Depression has negative effect on self-management, morbidity, mortality, glycaemic control, health costs [36,37] Also, there is a close relationship between depression and more frequent complications [38].

\section{Anxiety}

Next to depression, anxiety is a common problem among the diabetics [39]. According to survey $32.5 \%$ of diabetics are depressed, $18.3 \%$ of them are distressed, which is more frequent than in control team [40]. Anxiety can appear as lack of motivation, or reduced cooperation. Contrary to this excessive control may also indicate anxiety. The sign of fear of hypoglycaemia can be: more than six blood sugar measuring per a day, restriction of travel, frequent meals, restriction of sport, relative hypoglycaemia, and worries [41]. 


\section{Eating disorders}

At first Fairburn and Steel (1980) reported the relation between diabetes and anorexia nervosa; and also in this decade Hillard documented the joint occurrence of diabetes and bulimia [42]. Among diabetic women eating disorders are two times common, than among non-diabetics [43]. This can be caused by the nature of disease, patients always have to monitoring their eating habits, body weight, they have to fit with expectations, and these lead to frustration. The failure to comply with diet causes compunction, which can lead to too strict diet, and compensatory behaviour [44].

Péres and fellows (2006) interviewed 8 type 2 diabetic women, and they found, that the diabetes has strict negative effect on dietary feelings and attitudes of patients [45]. They have negative feelings about diet, there is common the sense of guilt, anger, and there is a constant desire to sweets.

According to researches bulimia is the most common eating disorders among type 1 diabetic women, and polyphagia among type 2 diabetics [46]. Insulin treatment can connect to weight gain, and the changing of the dose of insulin can help with slimming. Estimations show, that one third of diabetics modifiesor miss out the insulin dose to control their body weight [47]. Eating disorders have negative influence on the psychic status of patient and glycaemic control [11]. Inexplicable hypoglycaemia or ketoacidosis give cause for suspicion of eating disorders, mostly if that relative fast gets back to normal in hospital, under constant supervision. In this situation we should ask about eating habits, attitudes, worries about weight and appearance [48]. In short, psychological disorders have negative effect on the quality of selftreatment, because of this we have to recognize and treat these.

\section{Treatment of psychological disorders related to diabetes}

Despite of the larger occurrence of mental diseases among diabetics, they are not always diagnosed and treated $[49,50]$. It is recommended to analyse the mental status of the patient, if there is no medical reason of his complaints, sexual disorders, and chronic pain [51]. Only $10 \%$ of patients get psychological treatment, despite of the fact, that $41 \%$ of diabetics notice psychological signs, which have negative effect on the treatment [52]. The most common therapies of mental disorders are drug treatment, cognitive behavioural therapy, and interpersonal therapy [53]. According to the latest researches, antidepressants and psychotherapy are able to treat anxiety and eating disorders $[48,54-56]$.

During drug treatment we have to notice, that some drugs have negative effect on glycaemic control. Atypical antipsychotics gear up the insulin resistance. Diabetes can develop without the change of body weight. Similar drugs, like clozapine, olanzapine attach to GLUT4 glucose transporter protein, and inhibit them operation. Steroids have too diabetogenic effects, next to other side-effects (hypertension, obesities).

Psychological interventions have positive impact on self-care, glycaemic control, quality of life, emotional well-being, stress management, psychological signs, like depression [57].

\section{Self-treatment of the disease}

Term of successful self-treatment: individual abilities, appropriate doctor-patient communication, enough knowledge, motivation, social abilities. In the treatment of chronic diseases, $70 \%$ of patients do not follow the commissions of doctor. In this way, during the status of the patient does not develop, the doctor gets frustrated and feels him impotent [11,12-15].

The long-term cooperation with patients can be successful, if specialists give them appropriate theoretical knowledge, practical advice, and help them to be motivated and accept the illness.

There are two great tomes in German literature, which are written about behaviour-therapy [58,59]. Furthermore, many beneficial information are readable in Functional Insulin Treatment by Kinga Howorka (1997).

\section{Practical suggestions}

In this section writers would like to share their own experiences. Our aim is not to show all option for the therapy of diabetes $[60,61]$.

Our confession is the person-centred therapy from Carl Rogers. We believe that every person can develop, and gain, but they need empathy and unconditional acceptance [62]. It is important to create intimate atmosphere, where patient can be sincere, they can share us their fears and doubts. Our other confession is the transtheoretical model from Prochaska and DiClemente (1992), what helps to understand and support the changes of behaviour [63]. According to this theory the behaviour change has more stages, and in every stage there are typical changes. The significant basic of this theory, that before the clearly visibly stage of action, there are some other stages (pre-pragmatic stage, pragmatic stage, preparation stage), and if we recognise these stages, we can help the patient to get through of them [64]. We have to recognize, and communicate for the patient, that some hard period, and relapse are natural parts of changes, and he has to learn to handle them.

According to a survey, less than $20 \%$ of diabetics are ready for acting in time. At the same time, more than $90 \%$ of behaviour change programs are made for this less than $20 \%$, because of this, they are not successful. That is why, we think important, that patients in the other stages get appropriate treatment too [63].

Fit to the transtheoretic model, motivation interview [65] can help the patient to pledge himself to change, and intensify the intrinsic motivation for behaviour change. With this method, the patient can recognize the contradiction between his attitude and the desired aim.

According to researches all of this theories and methods are effective, with some other methods, enlarged their efficiency.

\section{Case Record}

Short introduction of the patient: 63 years old man, who have suffered from type 2 diabetes from 1997. Initially he got oral antidiabetic (OAD-) treatment. In 2001 he took part in a weight management group, which was organized by a pharmacy. He met there one of the organizers, who started the therapy of the diabetes and obesity. The group therapy did not have any significant effect [66].

Medical treatment: After the end of the group therapy, the individual therapy of the patient started. Next to the OAD therapy, there is started sibutramine therapy, for a year, 15 milligrams per day, but it did not affect significant slimming. The weight of the patient was 123 kilograms, his BMI was 38.5 .

Because of the inappropriate metabolic status next to the metformin, he got tablet treatment with glargine insulin, completed with basal insulin treatment in 2004. Later he got ICT (glargine + glulisin), with metformin. The weight of the patient was 135.5 kilograms in 2010 [67]. 
This time we started orlistat treatment, $3 \times 120 \mathrm{mg} /$ day, without any effect. Next to $2 \times 50$ E glargin, and $3 \times 40$ E glulisin $+2 \times 1000 \mathrm{mg}$ metformin, HbA1c was again under $8 \%$. The tension of the patient was proper with use of angiotensin receptor blocker (ARB), but later sleep apnea, and peripheral neuropathy appeared. In July of 2012. the weight of the patient gain to 140.8 kilograms, and there appeared cardiac complaints.

Behaviour therapy: This man is a great example for the Prochaska's spiral model. The patient have suffered from type 2 diabetes, with obesitas for 20 years. The group therapy, which was organized by pharmacy, gave good results for patients, who were in the state on acting, but he could not achieve anything. After this, the individual therapy took place at outpatient department, with drug treatment and lifestyle changing. It had no effect too. The third step was the behavioural therapy. The psychological survey excepted the strict psychological disorders (depression, eating disorders). The motivation interview, and the condition survey show, that according to the spiral model, the patient vacillates at the stage of preparation. By this time, the patient suffered from some complications (sleep apnea, neuropathy, angina complaints), which made him frightened. After the increasing of his motivation, we started a combined behaviour therapy, which consisted 4 elements: energy-poor diet, sport, regular medical control with body composition measurement, and psychological support. All of this strengthened with telemedicine.

Insulin doses were the follows: morning and evening 20-25 E glargine, also the half of the former dose, and $20 \mathrm{E}$ glulisin at noon.

The diet was $1000 \mathrm{kcal} /$ day $(200+600+200)$, from which $125 \mathrm{~g}$ was carbohydrate. Because the keeping of the diet was very difficult, we used the self-care model, which was created by Cooper (1994), and contains 6 stages:

1. Self-observe, diet diary

2. Create diet plan, and follow that

3. Analysis and cognitive processing of the mistakes

4. Problem solving

5. Change the diet plan to intrinsic motivation, from extrinsic

6. Change the way of thinking

We think useful to create a holiday, when the patient can "make mistakes". The aim of this is to change the concept of mistake, and show to the patient, that he can handle his own blood sugar level [12].

Also a useful method is the Blood Glucose Awareness Training, which was created by the University of Virginia [68]. With this help, the patient can recognize the signs of hypoglycaemia, and hyperglycaemia, this reduces the number of accidents, and makes the patient more confident. Just briefly described, the most important topics of behavioural therapy: early recognition of hypoglycaemia, avoidance of hypoglycaemia, correct intervention, differentiation between certain and misleading symptoms, mood's effect on blood sugar, the collective effect of insulin, sport, and eating [68].

These methods can effective increase the sense of security of the patient, which optimize his quality of life.

During the therapy patient observed his own condition, he wrote diet and weight diary, and he checked his urine every day, there wasn't acetonuria. We measured his body composition; he saw that the weight of his muscle was constant, he lost just fat. This increased his motivation.

Because of the age and weight of the patient we suggested half hour walking, and another half hour physical exercises per day.

The mental support was an important part of the therapy. The therapy contains the elements of the well-known behavioural therapy and cognitive parts (stimulus control, self-monitoring, and confirmation) $[69,70]$. After years, the patient felt himself competent in the management of his disease [71].

The intensive behaviour therapy ended in the summer of 2013. In this time the patient was 115.1 kilograms, so he lost 20 kilograms, his BMI decrease from 44.4 to 37.6 . His blood sugar levels in this time: fasting value $8.1 \mathrm{mmol} / \mathrm{l}$, after lunch $9.3 \mathrm{mmol} / \mathrm{l}$, evening $6.6 \mathrm{mmol} / \mathrm{l}$. HbA1c : $7.5 \%$. The results of the body composition measurement are on the Figure 1.

The behavioural therapy of diabetes has no end, it is a lifelong therapy. The patient is still under therapy.

The aim of this case record is to present the behavioural therapy of diabetes, which has to be a basic part of the therapy. This therapy has to be personalized. We cannot use protocols, we always have to confirm to the patient [72].

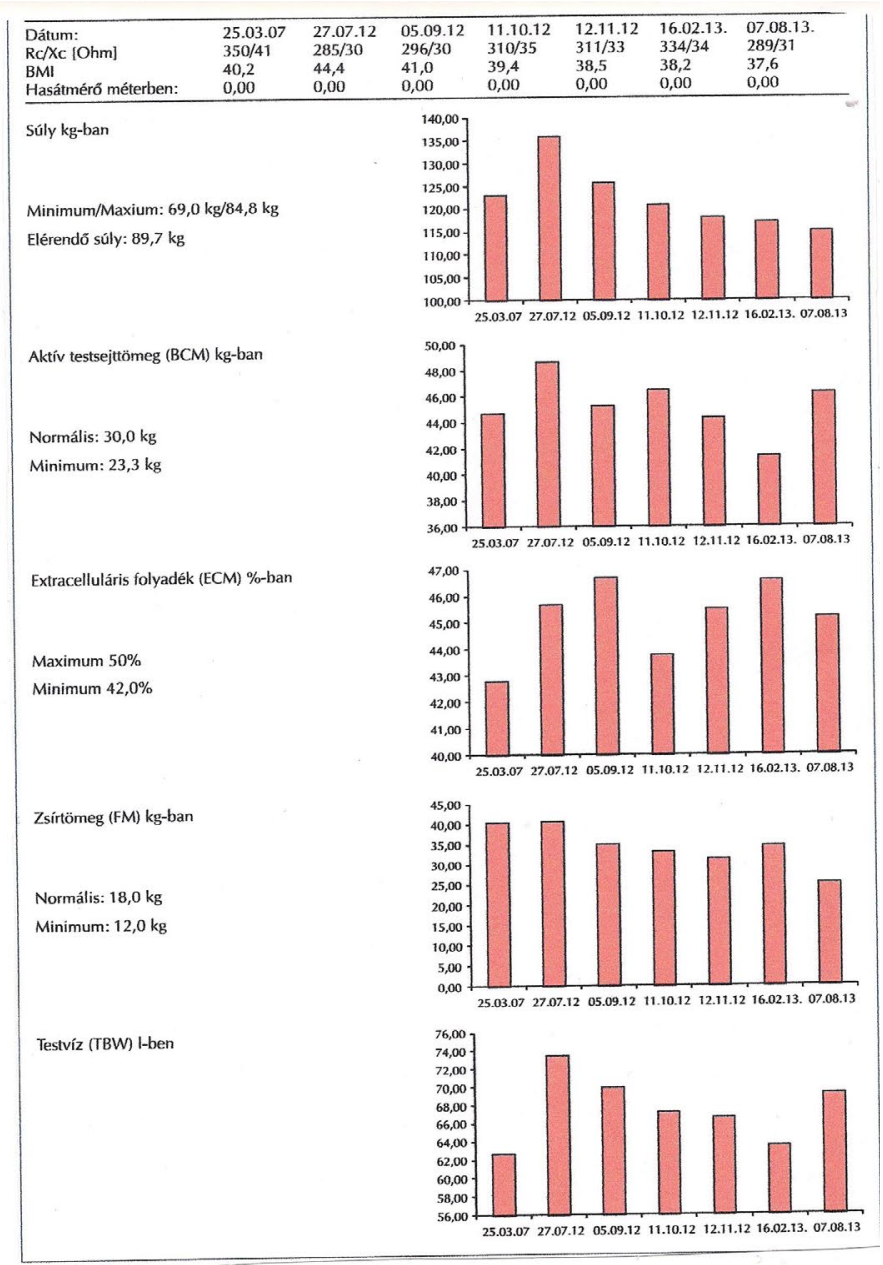

Figure 1. The results of the body composition measurement 


\section{Competence limits}

First of all, we have to clarify, that the therapy of diabetes is a medical task. The interdisciplinary approach of behavioural therapy can not mean the cancellation of the competence limits. The doctor, who treats the diabetes, needs more psychological knowledge; and the psychologist need more medical knowledge. We also have to state, that children's diabetes is in paediatrics competence. This is very important, because the lower age limit of type 2 diabetes gets lower and lower [73].

\section{Summary}

Next to a short overview of literature, our main purpose was to describe some practical behaviour therapy method, to help for doctors and patients. The behaviour therapy of diabetes is not a specific method; it has to be shaped for the patient in every case. These therapeutic events do not have predetermined thematic, usually we start with evaluation of somatic parameters, and after this we discuss psychological problems, adapting to the patient. During the therapy the therapist choose the method, which is the best to the patient. After this therapy the patient can be partly his own doctor.

\section{References}

1. Schwartz (2001) Weiss. Magatartastudomanyok. In: Buda B, Kopp M . Budapest: Medicina Könyvkiadó Zrt. p. 163.

2. Kopp M, Pik B (2003) Magatartasorvoslas es tudomany a XXI. szazadban. Magyar Tudomany 11:1352.

3. Fehm-Wolfsdorf G (2009) Diabetes mellitus. Göttingen: Hogrefe-Verlag.

4. Wild S, Roglic G, Green A, Sicree R, King H (2004) Global prevalence of diabetes: estimates for the year 2000 and projections for 2030. Diabetes Care 27: 1047-1053. [Crossref]

5. International Diabetes Federation. Diabetes: facts and figures. 2005. Letöltve: 2016. június 6 .

6. Gregg EW, Gu Q, Cheng YJ, Narayan V, Cowie CC (2007) Mortality trends in men and women with diabetes, 1971 to 2000. Annals of Internal Medicine 147: 149-55.

7. Huffman JC, DuBois CM, Millstein RA, Celano CM, Wexler D (2015) Positive Psychological Interventions for Patients with Type 2 Diabetes: Rationale, Theoretical model, and intervention development. J Diabetes Res 2015: 428349. [Crossref]

8. Sabate E (2001) WHO Adherence meeting report. World Health Organization, Geneva, Switzerland.

9. Edelwich J, Brodsky A (1998) Diabetes: caring for your emotions as well as your health. Reading, MA: Perseus Books.

10. Jimenez Chafey MI, Davila M (2007) Psicodiabetes. Avances en Psicología Latinoamericana 25: 126-43.

11. Rubin R (2000) Diabetes and quality of life. Diabetes Spectrum 13: 21.

12. Howorka K, Föv enyi J (1997) Funkcionalis inzulinterapia. Budapest: Springer Hungarica Kiado.

13. Lajkó K (2008) A viselked esvaltoztatas elm elete es gyakorlata. Budapest: Medicina Konyvkiado.

14. O’Neil HF, Drillings M (eds.). Motivació, elm elet es kutatas. Budapest: Vince Kiadó; 1999.

15. Polonsky WH (1999) Diabetes burnout: what to do when you can't take it anymore. Alexandria, VA: American Diabetes Association.

16. Skovlund SE, Peyrot M (2005) The Diabetes, Attitudes, Wishes and Needs (DAWN) Program: A new approach to improving outcomes of diabetes care. Diabetes Spectrum 18: $136-142$.

17. Gavard J, Lustman P, Clouse R (1993) Prevalence of depression in adults with diabetes: relationship to symptom and glucose control. Journal of Nervous and Mental Disorders 174: 736-742.

18. Jacobson AM (1996) The psychological care of patients with insulin-dependent diabetes mellitus. $N$ Engl J Med 334: 1249-1253. [Crossref]
19. Sal I, Susanszky E, Papp I (2003) Cukorbetegek eletminos ege a Hungarostudy Eg eszs eg Panel vizsgalat alapjan. Orv Hetil 154: 531-537.

20. Rubin RR, Peyrot M (1999) Quality of life and diabetes. Diabetes/Metabolism Research and Reviews 15: 205.

21. Franciosi M, Pellegrini F, De Berardis G, Belfiglio M, Cavaliere D, et al. (2001) The impact of blood glucose self-monitoring on metabolic control and quality of life in type 2 diabetic patients: an urgent need for better educational strategies. Diabetes Care 24: 1870-7.

22. Lustman PJ, Clouse RE (2005) Depression in diabetic patients, the relationship between mood and glycemic control. Journal of Diabetes and its Complications 19: 113-122.

23. Lustman PJ, Clouse RE (2007) Depression in diabetes: the chicken or the egg? Psychosom Med 69: 297-299. [Crossref]

24. Bergner M (1987) Development, testing and use of the Sickness Impact Profile. In: Walker SR, Rosser RM. Quality of life: assessment and application Lancaster: MTP p.79-94.

25. Novak M, Stauder A, Mucsi I (2003) Az eletminos eg vizsgalatanak jelentos ege es gyakorlati szempontjai. Orv Hetil 144: 1031-1038.

26. Gonder-Frederick LA, Cox DJ, Ritterband LM (2002) Diabetes and behaviora medicine: the second decade. J Consult Clin Psychol 70: 611-625. [Crossref]

27. Lustman PJ, Griffith LS, Clouse RE (1997) Depression in Adults with Diabetes. Semin Clin Neuropsychiatry 2: 15-23. [Crossref]

28. Colton PA, Olmsted MP, Daneman D, Rydall AC, Rodin GM (2007) Five year prevalence and persistence of disturbed eating behavior and eating disorders in girls with type 1 diabetes. Diabetes Care 30: 2861-2862.

29. Culpepper L (2009) Generalized anxiety disorder and medical illness. Journal of Clinical Psychiatry 70: 20-24.

30. DeGroot M, Anderson R, Freedland KE, Clouse RE, Lustman PL (2001) Association of depression and diabetes complications: A metanalysis. Psychosomatic Medicine 63: 619-630.

31. Anderson RJ, Freedland KE, Clouse RE, Lustman PJ (2001) The prevalence of comorbid depression in adults with diabetes: a meta-analysis. Diabetes Care 24: 1069 1078. [Crossref]

32. Ali S, Stone MA, Peters JL, Davies MJ, Khunti K (2006) The prevalence of co-morbid depression in adults with type 2 diabetes: A systematic review and meta-analysis. Diabetic Medicine 23: 1165-1173.

33. Li C, Ford ES, Strine TW, Mokdad AH (2008) Prevalence of depression among U.S adults with diabetes: Findings from the 2006 behavioral risk factor surveillance system. Diabetes Care 31: 105-107.

34. Lustman P, Clouse R (2004) Depression: a potentialle modifiable risk factor for diabetes and its complications. Diabetes Spectrum 17: 147-164.

35. Jerant AF, von Friederichs-Fitzwater MM, Moore M (2005) Patients' perceived barriers to active self-management of chronic conditions. Patient Education and Counselling 57: 300-307.

36. Lustman PJ, Anderson RJ, Freedland KE, de Groot M, Carney RM, et al. (2000) Depression and poor glycemic control: a meta-analytic review of the literature. Diabetes Care 23: 934-942. [Crossref]

37. Chao J, Nau DP, Aikens JE, Taylor SD (2005) The mediating role of health beliefs in the relationship between depressive symptoms and medication adherence in persons with diabetes. Research in Social and Administrative Pharmacy 1: 508-25.

38. DeGroot M, Anderson R, Freedland KE, Clouse RE, Lustman PL (2001) Association of depression and diabetes complications: A metanalysis. Psychosomatic Medicine 63: 619-630.

39. Culpepper L (2009) Generalized anxiety disorder and medical illness. Journal of Clinical Psychiatry 70: 20-4.

40. Shao K (2008) Psychological disorders and their effect on the therapeutic efficacy in type 2 diabetes. Chinese Journal of Diabetes 16: 301-303.

41. Fairburn CG, Steel JM (1980) Anorexia nervosa in diabetes mellitus. Br Med J 280: 1167-1168. [Crossref]

42. Hillard JR, Lobo MC, Keeling RP (1983) Bulimia and diabetes: a potentially lifethreatening combination. Psychosomatics 24: 292-295. [Crossref]

43. Colton PA, Olmsted MP, Daneman D, Rydall AC, Rodin GM (2007) Five year prevalence and persistence of disturbed eating behavior and eating disorders in girls with type 1 diabetes. Diabetes Care 30: 2861-2862. 
44. Steel JM, Young RJ, Lloyd GG, Macintyre CC (1989) Abnormal eating attitudes in young insulin-dependent diabetics. Br J Psychiatry 155: 515-521. [Crossref]

45. P eres DS, Franco LJ, dos Santos MA (2006) [Eating behavior among type 2 diabetes women]. Rev Saude Publica 40: 310-317. [Crossref]

46. Young-Hyman DL, Davis CL (2010) Disordered eating behavior in individuals with diabetes: Importance of context, evaluation and classification. Diabetes Care 33: 683689.

47. Larranaga A, Docer MF, Garcia-Mayor RV (2011) Disordered eating behaviors in type 1 diabetic patients. World Journal of Diabetes 2: 189-195.

48. Marcus M, Wing R (1990) Eating disorders and diabetes: diagnosis and management. Diabetes Spectrum 3: 361.

49. Katon W, Von Korff M, Ciechanowski P, Russo J, Lin E, et al. (2004) Behavioral and clinical factors associated with depression among individuals with diabetes. Diabetes Care 27: 914-920.

50. Lustman P, Clouse R (2004) Practical considerations in the management of depression in diabetes. Diabetes Spectrum 17: 160-166.

51. American Psychiatric Association (2000) Diagnostic and statistical manual of mental disorders (4th Edition). Washington, D.C.

52. Peyrot M, Rubin RR, Lauritzen T, Snoek FJ, Matthews DR, et al. (2005) Psychosocial problems and barriers to improved diabetes management: results of the Cross-National Diabetes Attitudes, Wishes and Needs (DAWN) Study. Diabet Med 22: 1379-1385. [Crossref]

53. Nathan P, Gorman J (1998) A guide to treatments that work (2ndEdition). New York: Oxford University Press.

54. Lustman PJ, Griffith LS, Clouse RE, Freedland KE, Eisen SA, et al. (1997) Effects of nortriptyline on depression and glycemic control in diabetes: results of a double-blind, placebo-controlled trial. Psychosom Med 59: 241-250. [Crossref]

55. Lustman PJ, Griffith LS, Freedland KE, Kissel SS, Clouse RE (1998) Cognitive behavior therapy for depression in type 2 diabetes mellitus. A randomized, controlled trial. Ann Intern Med 129: 613-621. [Crossref]

56. Williams JW Jr, Katon W, Lin EH, Noel PH, Worchel J, et al. (2004) The effectiveness of depression care management on diabetes-related outcomes in older patients. Ann Intern Med 140: 1015-1024. [Crossref]

57. Markowitz SM, Gonzalez JS, Wilkinson JL, Safren SA (2001) Review of treating depression in diabetes: Emerging findings. Psychosomatics 52: 1-18.
58. Ehlert U (2003) Verhaltensmedizin. Springer.

59. Broda M, Köllner V (2005) Praktische Verhaltensmedizin. Thieme.

60. Howorka K. Funktionelle insulintherapie (1996) Praxis und didaktik. Springer.

61. Kopp M, Sal I (1998) Funkcionalis inzulinterapia (könyvismertet es). Lege Artis Medicinae 8: 470-472.

62. Tringer L(2007) A gyógyító besz elget es. Budapest: Medicina Könyvkiadó Zrt.

63. Prochaska JO, DiClemente CC (1992) The transtheoretical approach. In: Norcross JC Goldfried MR (eds.). Handbook of Psychotherapy Integration. New York: Basic Books p. $147-72$.

64. Prochaska JO, Norcross JC, DiClemente CC (2009) Valódi újrakezd es. Ursus Libris.

65. Miller WR, Rollnick S (2012) Motivational interviewing: Preparing people for change 3rd edition. New York, NY, USA: Guilford Press.

66. Christie D, Channon S (2014) The potential for motivational interviewing to improve outcomes in the management of diabetes and obesity in paediatric and adult populations: a clinical review. Diabetes, Obesity and Metabolism 16: 381-387.

67. Cooper PJ (1994) Farkas ehs eg. Budapest: Springer Hungarica Kiadó.

68. Gonder-Frederick L, Cox D, Clarke W, Julian D (2000) Blood glucose awareness training. In: F.J. Snoek, \& T.C. Skinner (Eds.). Psychology in diabetes care. (168-206) Wiley, Oxford, UK.

69. Foster GD, Makris AP, Bailer BA (2005) Behavioral treatment of obesity. American Journal of Clinical Nutrition 82: S230-S235.

70. Levy RL, Finch EA, Crowell MD, Talley NJ, Jeffery RW (2007) Behavioral intervention for the treatment of obesity: strategies and effectiveness data. Am J Gastroenterol 102: 2314-2321. [Crossref]

71. Török E, Harsanyi L (2014) [The measureable clinical signs of malnutrition: the clinical significance of body composition - bioimpedance - analysis]. Orv Hetil 155: 2016-2020. [Crossref]

72. Simon K (2016) Egys eges belgyógyaszat - utópia vagy realitas? Magy Belorv Arch 69: 289-294.

73. Thomas NJM, Jones S, Weedon M, Hattersley A, Oram R (2016) Classifying diabetes by type 1 genetic risk shows autoimmune diabetes cases are evenly distributed above and below 30 years of age. EASD 264.

Copyright: (C2019 Sal I. This is an open-access article distributed under the terms of the Creative Commons Attribution License, which permits unrestricted use, distribution, and reproduction in any medium, provided the original author and source are credited. 